\title{
ДЕРЖАВНА ОСВІТНЯ ПОЛІТИКА ТА СТВОРЕННЯ КИЇВСЬКОГО НАВЧАЛЬНОГО ОКРУГУ В РОКИ ПОПЕЧИТЕЛЬСТВА Є. Ф. ФОН БРАДКЕ (1832-1838 РР.)
}

Кільова Г. О. Державна освітня політика та створення Київського навчального округу в роки попечительства С. Ф. фон Брадке (1832-1838 рр.)

У статті розглядається початковий період створення Київського навчального округу, коли закладався фундамент майбутнього розвитку. Автор звертає увагу на участь професорської колегії Університету Св. Володимира у життєдіяльності округу. Представлена особа першого попечителя Е.Ф.фон Брадке, завдяки знергічним і рішучим зусиллям якого відбувалося становлення Київського навчального округу.

Ключові слова: попечительство, Київський навчальний округ, Є. Ф. фон Брадке, міністерство, університет, освітня політика.

Килевая Г. А. Государственная образовательная политика и создание Киевского учебного округа в годы попечительства Е. Ф. фон Брадке (1832-1838 гг.).

В статье рассматривается начальный период создания Киевского учебного округа, когда закладывался фундамент будущего развития. Автор обращает внимание на участие профессорской коллегии Университета Св. Владимира в жизнедеятельности округа. Представлена личность первого попечителя Е. Ф. фон Брадке, благодаря знергичным и решительным усилиям которого происходило становление Киевекого ученого округа.

Ключевые слова: попечительство, Киевский учебный округ, Е. Ф. фон Брадке, министерство, университет, образовательная политика.

Kilevaya G. A. Establishment and functioning of the Kiev school district during the guardianship EF background Bradtke (1832-1838 years).

This article discusses the creation of the initial period of the Kiev school district, when the foundation for future development. The author draws attention to the participation of the college professor's University of St. Vladimir in the life of the district. Presented the first person trustee EF background Bradtke, thanks znergichnym and determined efforts which occurred the formation Kievekogo scientist District.

Освіта - одна 3 найважливіших складників державної політики. Формулюючи засадничі принципи функціонування освітньої галузі, забезпечуючи високий суспільний авторитет викладацьких кадрів, кожна держава тим самим закладає підвалини стабільності свого майбутнього розвитку: політичного, економічного, наукового, духовного.

Вітчизняна система освіти більш ніж півстоліття перебувала в лещатах ідеологічної машини комуністичного режиму. Виховання підростаючого покоління відбувалося згідно з догмами марксизму-ленінізму, а доцільність нововведень чи реорганізації навчального процесу відповідно до вимог часу розглядалася виключно через призму формування «нової радянської людини» та «єдиного радянського народу».

Ситуація, що існувала протягом сімдесяти років, змінилася наприкінці 80-хпочатку 90-х років ХX ст., коли з розпадом колишньої імперії освітянська галузь України постала перед неминучістю проведення реформ на всіх етапах від початкової до вищої школи. Кризова ситуація 90-х років ХХ століття змусила громадськість уважніше придивитися до проблем української освітньої галузі, викликала дискусії щодо подальших шляхів розвитку вітчизняної школи. Серед обговорюваних варіантів 
реформування системи освіти не останнє місце, на нашу думку, повинна посідати ідея створення шкільних округів, котрі мобільніше реагуватимуть на потреби часу, а їх поява зможе підвищити рівень знань учнів завдяки співпраці влади, педагогічних колективів та батьків у питаннях забезпечення ефективності навчального процесу, спільного розв'язання найбільш болючих проблем сучасної школи.

Ідея створення шкільних округів не нова, і на українських землях, що входили до складу Російської імперії, функціонували шкільні округи. Тому в контексті дискусій про перспективи і шляхи подальшого розвитку вітчизняної освіти розгляд історії існування навчальних округів $є$ особливо актуальним з огляду на можливість вивчення досвіду попередніх століть, уникнення помилок та впровадження на практиці найбільш позитивних елементів.

Питання функціонування навчальних округів на українських землях розглядалося дослідниками здебільшого у контексті історії освіти Російської імперії загалом [1] та вивчення окремих ланок освітньої системи, як-от: початкової, середньої, вищої, недільної школи зокрема [2]. Детальних аналітичних розвідок, присвячених проблемам створення та існування навчальних округів, і особливо Київського, на сучасному етані розвитку української науки недостатньо. Саме початковому етапу Київського навчального округу i присвячено статтю. Окремо виділяється постать першого попечителя округу Єгора Федоровича фон Брадке, активна діяльність якого заклала підвалини стабільного функціонування округу в наступні десятиріччя.

Навчальні округи з'явилися в Російській імперії на початку XIX ст. Поява їх пов'язана 3 реформами в системі вищих і центральних державних органів, головним ідеологом яких був М. Сперанський. Саме він та його однодумці з кола молодих друзів імператора Олександра I обгрунтували необхідність створення міністерств, Комітету міністрів, Державної Ради та інших органів влади. За основу впроваджуваних реформ було взято досвід наполеонівської Франції. Звідти запозичили галузевий поділ функцій за міністерствами та саму ідею Державної Ради. Під час проведення реформ було створено вісім міністерств. Структурними підрозділами кожного міністерства були канцелярія міністра і департаменти. Кожен департамент, у свою чергу, поділявся на канцелярію і відділення, а останні - на столи. Кожному міністерству на місцевому рівні підпорядковувалась низка закладів цього відомства [3; 7-8].

Центральним державним органом у системі освіти 31802 року виступало Міністерство народної освіти. На місцях йому підпорядковувалися навчальні округи та дирекції народних училищ. Першопочатково територія європейської частини імперії поділялася на сім навчальних округів (С.-Петербурзький, Московський, Казанський, Дерптський, Віленський, Одеський і Харківський) [4, с. 80-82]. Територія сучасної України входила до трьох із них: Віденського, Харківського й Одеського. Події польського повстання 1830-1831 років наочно продемонстрували царизму, яку загрозу несе режиму національно-визвольний рух підкорених народів, складовим елементом якого була учнівська молодь. Тому з 30 -х років XIX ст. на землях, що входили до складу Речі Посполитої, проводиться політика деполонізації та русифікації. Задля зменшення польського впливу на зазначених територіях у 1832 р., Віленський навчальний округ розформовується. На його базі створюються два нові округи: Білоруський і Київський. Останній був «образован из училищ губерний Киевской, Черниговской, Волынской и Подольской» [5, с. 406]. Для потреб новоствореного округу виділялася певна сума i призначався попечитель [5, с. 407].

Розпочинати непросту місію організатора навчального процесу в Київському навчальному окрузі випало першому попечителю Сгору Федоровичу фон Брадке (17961861) [6]. Він народився 16 травня (ст. ст.) 1796 року в Езельському окрузі (нині- 
Естонія) у дворянській родині зрусифікованих вихідців зі Швеції. До шести років хлопець виховувався у тітки, потім у 1802-1806 рр. навчався у приватній школі. У 1806 році Єгор переїхав до батьківського маєтку Верхов'є Вітебської губернії, але вже влітку 1806 року батько віддав його на навчання до загальних класів Гірничого кадетського корпусу в С.-Петербурзі. Отримавши в останньому добру підготовку, Брадке у 1810 р. залишив корпус: предмети гірського відомства «не соответствовали ни целям моего отца, ни моим желаниям» [7, с. 20]. Майже рік він працював у канцелярії батька, призначеного губернатором до Вятки, а у вересні 1811 р. Брадке вступив до школи колоновожатих у С.-Петербурзі. Особливий вплив на формування світогляду майбутнього державного діяча мали три брати Муравйови, що викладали у школі математику і військові науки, про що згадував Брадке в автобіографічних записах.

31815 року Єгор Федорович перебував на військовій службі: брав участь у поході на Париж, де 3 березня до вересня перебував у розпорядженні чергового генерала головного штабу, згодом служив у Могильові при штабі Барклай-де-Толлі (з 1816 р.). У листопаді 1817 р. Брадке отримав відрядження до окремого корпусу військових поселень під управлінням графа Аракчеєва, а після створення штабу військових поселень увійшов до його складу. 31823 по 1824 роки і в 1825 році Єгор Федорович виконував обов'язки оберквартирмейстера військових поселень. У 1827 р. Брадке призначили оберквартирмейстером 3-го резервного поселеного кавалерійського корпусу. У ті ж роки він отримав чергові військові звання: капітана (1822 р.), підполковника (1826 р.) і полковника (1830р.).

У 1831 р. Брадке брав участь у придушенні польського повстання, відзначився в «генеральном сражении против мятежников под Прагою, на полях Гроховских (13 февр.), был награжден орденом св. Владимира 3 ст., а позднее (5 авг.) - за отличное мужество, оказанное в кавалерийском деле у селения Брониц, близ Варшавы, золотою шпагою с надписью «за храбрость»» [8, XIV]. Протягом серпня-жовтня 1831 року керував справами канцелярії варшавського губернатора. У зв'язку з хворобою Єгор Федорович подав рапорт про відставку з військової служби і 9 вересня 1832 року його прохання задовольнили. 3 чином дійсного статського радника він був зарахований до Міністерства народної освіти, а вже 14 грудня того ж року його призначили попечителем Київського навчального округу. Після семирічного перебування на цій посаді Брадке 5 грудня 1838 року за його власним бажанням було звільнено, хоча він керував округом до прибуття нового попечителя князя С. Давидова. Подальша службова діяльність першого попечителя Київського навчального округу була пов'язана 3 Міністерством державного майна: у квітні 1839 року його призначили членом Ради міністерства, а згодом - директором 3-го департаменту цього державного органу. Про діяльність Брадке на посаді директора департаменту згадував академік К. Веселовський: «...энергическою деятельностью Брадке департамент был выведен из того зачаточного хаотического состояния, в каком он был при первом директоре бароне Деллинсгаузене... [були. - Авт.], составлены уставы Горыгорецкого института, образцовых ферм, школ виноделия и шелководства; поставлено на прочную почву дело о кадастре; упорядочен личный состав департамента, привлечены сведущие чиновники» [9, с. 22-24].

Погіршення стану здоров'я примусило Брадке залишити директорську посаду в Міністерстві державного майна, але вже 16 січня 1844 року його призначили сенатором iï відділення 3-го департаменту Сенату. 3 сумлінністю ставився Єгор Федорович і до нових обов'язків: у 1851 р. він проводив ревізію Херсонської губернії, виконував інші доручення. У 1854 р. Брадке знову повернули на ниву освіти: 20 вересня його призначили попечителем Дерптського навчального округу на посаду, яку він обіймав до 
кінця життя. Багаторічна службова діяльність Єгора Федоровича була відзначена державними нагородами: орденами св. Володимира 2, 3 і 4 ст., св. Станіслава 1 і 2 ст., св. Анни 1, 1 ст. $з$ імператорською короною і 2 ст., Білого Орла, Олександра Невського та золотою табакеркою з портретом імператора, прикрашеним діамантами. У 1860 р. Брадке отримав чин дійсного таємного радника. Стипендії його імені були засновані в Дерптському ветеринарному училищі та Університеті Св. Володимира.

Неодмінно енергійною і відповідальною людиною характеризували Єгора Федоровича сучасники. Вже згадуваний академік К. Веселовський писав у своїх спогадах «о его [Брадке. - Авт.] положительном уме и административной опытности». Перший попечитель Київського навчального округу «обладал большою знергиею и воспитал в себе в замечательной степени чувство долга», а його ставлення до справи не було показним чи примусовим, колег і підлеглих він заохочував власним прикладом: «...работая сам неустанно, Брадке умел и своих подчиненных заохотить к труду и возбудить в них интерес к делу... единственно нравственным влиянием на них» [9, c. 22]. Коротко, але влучно охарактеризував Брадке академік С.-Петербурзької Академії Наук і професор столичного університету О.В. Нікітенко. Під час розгляду міністром народної освіти кандидатур на посаду попечителя Дерптського навчального округу Нікітенко заявив: «Вы в числе других назвали Брадке... Чего же лучше? Он уже был попечителем в Києве. Это человек опытный, образованный и благородный» [19, с. 384]. Позитивно оцінював діяльність Є.Ф. фон Брадке у Києві i автор першої історії Університету Св. Володимира В. Шульгін, який відзначав гуманність попечителя, його постійну турботу про викладачів і студентів [20, с. 65-66].

Призначення на посаду попечителя Є. Ф. фон Брадке мало вирішальне значення для швидкого та успішного розвитку освітніх закладів округу. Для нього не існувало національностей у процесі розв'язання кадрових питань, а існували здібні люди і нездари. Енергійна діяльність попечителя, який міг твердо і послідовно відстоювати свою позицію, дала змогу поліпшити освітню ситуацію в краї уже в перші роки існування округу. Результати діяльності Брадке були помітні одразу. Згідно зі статистичними даними у Київському навчальному окрузі в 1833 році нараховувалося: гімназій - 7 (у 1832 р. - 5), повітових училищ - 22 (18), народних, приходських i сільських училищ - 20 (8), приватних пансіонів і конвіктів - 14 (11). Усього ж кількість навчальних закладів збільшилась із 44 у 1832 р. до 65 у 1833 р. [10, с. 68-69]. Ще більш переконливим було зростання кількості учнів: у 1832 р. - 3 515, а у 1833 р. - 4325 [10, c. 72-73]. Збільшення за рік кількості учнів на 810 чоловік було одним із кращих показників серед інших округів. Випередити Київський округ зміг лише Харківський, де на кінець 1833 року учнів збільшилося на 853 особи у порівнянні з 1832 р., але потрібно врахувати і розміри округів, у чому Київський значно поступався Харківському [11]. Інші навчальні округи не могли презентувати такі результати, а в деяких відбулося навіть зменшення кількості молодих людей, що навчалися. Вже за перший рік попечительства Єгора Федоровича в Київському навчальному окрузі були відкриті: 1) гімназії - у Вінниці, Луцьку, Житомирі і Кам'янці-Подільському; 2) повітові училища - в Махновці, Радомишлі, Суражі, в Києві перенесене з Печерська на Поділ, в містечках Каневі і Клевані. Окрім того, «предписано открыть таковые же в местечках Мендзибоже и Немирове; сверх того подобные заведення должны быть учреждены вскорости в городах: Остроге, Староконстантинове и Новограде-Волынском: открьпие их приостановилося только на некотрое время за неимением на первый случай удобного помещения» [ 12, ССІУ]. Із приходських училищ відкрилися знову: в Київській губернії - в Чигирині, Черкасах, Сквирі, Таращі, Радомишлі, Махновці, Звенигородці і Василькові; у Волинській губернії- в Житомирі, Новограді-Волинському, Луцьку, 
Рівному, Несвічі і Ольську; в Подільській губернії - в Кам'янці-Подільському, Вінниці й Клевані [12, ССІУ-ССУ].

Навчальні заклади вищого рівня, ніж гімназії та училища, в Київському навчальному окрузі були представлені у 1832 році двома ліцеями: Волинським у Крем'янці та князя Безбородька у Ніжині. В останньому, згідно з поданням попечителя Є.Ф. фон Брадке до Комітету Міністрів, відбувалося реформування відповідно до статуту 7 жовтня 1832 р.: «закрывая ежегодно по одному нижнему классу, в высших же с началом нового учебного года прекратить преподавание предметов, не положенных по сему Уставу, и вводить назначенные вновь, соображаясь со способами сего заведення и по усмотрению его начальства» [12, ССШ-ССГУ]. На кінець 1833 року у ліцеї кн. Безбородька за штатом нараховувалося 18 чиновників і викладачів, 284 ліцеїсти, 18 чоловік були випущені з правами на класні чини [12, CCIV].

Період перетворень переживав і Волинський ліцей. Ще у 1830-1832 pp. його декілька разів закривали, але згодом заняття поновлювалися. У 1832 р. у С.-Петербурзі ухвалили рішення перенести ліцей до Києва і в 1832-1833 роках вирішувалися організаційні питання. Як зазначав М.П. Василенко у своєму дослідженні про Крем'янецький ліцей, «відколи було на посаду куратора Київської Шкільної Округи призначено фон Брадке, справа 3 переводом ліцею до Києва посунулася наперед. 2-го травня 1833 р. Комітет Міністрів ухвалив низку заходів, що їх запропонував був київський куратор відносно переводу. 21 червня 1833 р. куратор заснував у Києві окрему комісію, щоб упорядкувати ліцей» [13, с. 44-45]. Але подальша доля ліцею вирішилася несподівано чином. 8 листопада 1833 р. імператор Микола I видав указ про заснування у Києві університету 3 правом іменування Університетом Св. Володимира [13, с. 62-64]. 25 грудня того ж року з'явився тимчасовий статут нового закладу, а вже навесні 1834 р. свою діяльність розпочала Рада Університету. Як і в справі переведення до Києва Волинського ліцею, так і в організації та відкритті Київського університету основний тягар обов'язків ліг на плечі попечителя С. Ф. фон Брадке. Йому необхідно було підшукати відповідні приміщення для занять, сформувати викладацький штат, турбуватися про розміщення студентів і водночас керувати справами округу.

3 покладеними на нього завданнями та клопотами щодо облаштування у Києві університету Брадке успішно впорався. 15 липня 1834 року у Києві в присутності посадових осіб місцевого краю, чиновників, дворян, професорів і студентів відбулося урочисте відкриття Університету Св. Володимира [14, с. 296-299]. Від моменту заснування університет став центром Київською навчального округу. Згідно 3 тимчасовим статутом $1833 \mathrm{p}$. ректор університету заміщав попечителя під час відряджень чи хвороби останнього, а серед обов'язків Ради Університету було «определение и увольнение учителей и других чиновников как в Университете, так и в училищах его Округа» $[15$, с. 66]. Окремо слід згадати про розділ XII «Об училищном комитете» статуту 1833 р. До училищного комітету входили три професори і синдик під головуванням ректора. Комітет мав керувати лише навчальною частиною училищ округу. Щорічно комітет складав звіт про стан підвідомчих навчальних закладів i подавав до Ради Університету, яка включала його до загальноуніверситетського звіту. Училища округу мали оглядатися візитаторами ж мінімум раз на два роки [15, с. 74]. Професори Університету Св. Володимира досить часто відряджалися для візитації. Так, професор загальної історії В.Ф. Цих прибув з Харкова до Києва 21 квітня 1834 р. [16, c. 33], а вже на пропозицію попечителя від 7 травня за № 1059 його відрядили візитатором для огляду Подільської губернської і Вінницької гімназій та уманських 
приватних пансіонів [16, с. 49]. Пізніше В. Цих оглядав Кам’янець-Подільську гімназію та Київський приватний пансіон [16, с. 313-315 зв., 364].

Загалом діяльність Ради та Училищного комітету була ефективним елементом освітньої політики. Намагаючись контролювати приватну освіту, Рада Університету не лише відряджала візитаторів, а й вирішила «екзаменувати» домашніх учителів у «казенних» закладах: у Київській губернії- в Університеті Св. Володимира; у Чернігівській - у Ніжинському ліцеї; у Волинській - у гімназіях Волинській та Клеванській; у Подільській губернії - у Кам'янець-Подільській та Вінницькій гімназіях [17, с. 144].

Рада Університету Св. Володимира брала участь і в обговоренні різних освітніх проектів. На засіданні 20 жовтня 1834 р. розглядався проект про перетворення повітових училищ у трьох західних губерніях Росії. Проект передбачав три види училищ: а) гімназії - губернські й повітові (що не мали своєї дирекції); б) повітові училища дворянські (1-го розряду) і міщанські (2-го розряду); в) парафіяльні училища. Було запропоновано відкрити нові чотирикласні повітові училища: Уманське та Олександрівське (у Київській губерніі), Острозьке і Теофільпольське (у Волинській губерніі), Меджибозьке, Балтське і Могилівське (у Подільській губернії). Цей проект зі складеним штатом був поданий на розгляд керівництва, а 16 червня 1835 року зміни були схвалені міністерством. Наказувалося реорганізувати гімназії і училища Західного краю 31 січня 1836 року. У період серпня 1835 р. - січня 1836 р. Правління Університету вирішило справу щодо фінансування проекту перетворення повітових училищ Київської, Волинської і Подільської губерній [17, с. 141].

Важливою у справі керівництва округом була роль ректора університету. У 1834 p. перший ректор М. Максимович виконував функції попечителя 312 до 19 грудня, а в 1835 р. вже двічі - 318 квітня до 11 травня і 7 до 16 вересня [17, с. 142-145]. Надалі наступні ректори В. Цих та К. Неволін виконували обов'язки попечителя, коли останній виїжджав 3 оглядом училищ та гімназій округу або перебував у С.-Петербурзі. У такий спосіб університет у період попечительства Є. Ф. фон Брадке був тісно пов'язаний 3 життям Київського навчального округу. Це давало змогу контролювати навчальний процес, реагувати на освітні потреби місцевого населення, враховувати специфіку краю в проектах реорганізації освітніх закладів, а звіти викладачів після візитації давали можливість скласти об'єктивну картину недоліків та позитивів у навчанні учнів училищ та гімназій, ураховуючи їх у майбутніх змінах. Перебування на посаді попечителя Київського навчального округу завершилося для Є.Ф. фон Брадке наприкінці 1838 р. Указом імператора від 5 грудня 1838 р. Брадке було звільнено з «должности попечителя Киевского Учебного Округа, с назначением его Членом Главного Правлення Училищ и с содержанием по 6000 рублей в год из Государственного Казначейства» [18, СХ]. Того ж дня на посаду попечителя було призначено мінського цивільного губернатора князя С. Давидова [18, СУШ].

Шестирічний період попечительства Є.Ф. фон Брадке був позначений в історії Київського навчального округу вагомими результатами, і найголовніший 3 яких відкриття університету в Києві. Попечителю доводилося працювати в умовах, коли місцева еліта була переважно польської національності і намагалася зберегти в краї той стан справ, що і існував на початку XIX ст. в роки Ф. Чацького. Як офіційна особа Брадке виступав провідником державної освітньої політики, що визначалася відомою формулою С. Уварова «самодержавність, православ'я, народність». Завдяки притаманним йому рисам характеру, попечителю вдавалося уникати гострого протистояння 3 місцевим дворянством i чиновництвом та налагодити звичний навчальний процес в навчальних закладах округу, що був порушений під час повстання 
1830-1831 pp. До заслуг попечителя відносяться постійно зростаюча кількість учнів і студентів, відкриття нових гімназій, училищ та шкіл, проведення реформ з реорганізації училищ округу. Сучасники підкреслювати виняткову роль попечителя в успішному функціонуванні Київського навчального округу. Це підтверджується порівнянням із діяльністю наступників Брадке на посаді попечителя князя С. Давидова та генерала О. Траскіна. У роки попечительства Брадке Київський навчальний округ утвердився як адміністративна одиниця, в Університеті Св. Володимира зосередилися кращі викладачі Крем'янецького ліцею та молоді кадри, запрошені 3 інших вузів. Протягом 18321838 рр. в окрузі були створені передумови для стабільного функціонування навчальних закладів, закладено фундамент для подальшого розвитку вищої освіти.

\section{Література}

1. Сірополко С. Історія освіти в Україні. К, 2001; Рождественский С. Очерки по истории систем народного просвещения в России в ХУІП-ХІХ веках. Т. 1. - СПб., 1912; Мединский Е. Н. История русской педагогики с древнейших времеи до великой пролетарской революции. - М, 1936, Демков М.И. История русской педагогики. - Часть III. - Новая русская педагогия (XIX век).- М, 1909. 2. Шмидт Е. История средних учебных заведений в России / Е. Шмидт. - СПб., 1878; К истории народного образования на Украине в 1-ой четверти ХІХв.// Киевская старина. - 1898. - №5; Доманицкий В. К К истории частных пансионов в Киевской губ. в начале ХІХв. // Киевская. старина. -1901. - № 6. 3. Высшие и центральные государственные учреждения России. 1801-1917 гг. - Т. 1 - Высшие государственные учреждения. СПб.: Наука, 1998. 4. Рождествеиский С. В. Исторический обзор деятельности Министерства Народного Просвещения 1802-1902 / С. В. Рождественский. - СПб., 1902. 5. Сборник постановлений по Министерству Народного Просвещения. - 7.2. Царствование Императора Николая I. Отделение I. 1825-1839. - СПб., 1864. 6. Детальніше біографію С.Ф. фон Брадке див.: Столетие Киевской первой гимназии (1809-1811-1911 гг.) - Т. 1-11. - К, 1911; Воспоминания К. С. Веселовского /Русская старина. -1903. - Т. 116. - №10; Русский биографический словарь. [Т. 3]: БетанкурБякстер. - СПб., 1908; Брадке Е. Ф. Автобиографические записки // Русский архив. 1875. - № 1, 3; Новый энциклопедический словарь под общей редакцией академика К. К. Арсеньева. -Т. 7. - СПб., 1912. 7. Брадке Е. Ф. Автобиографические записки / Е. Ф. Брадке // Русский архив. -1875. - №1. 8. Столетие Киевской первой гимназии (1809-1811-1911 гг.). - Т. 1-11. - К, 1911. 9. Воспомииания К. С. Веселовского// Русская старина. - 1903.-Т. 116. - № 10. 10. Журнал министерства народного просвещения. - 1834. - Кн. 2. - № 4, апрель.

УДК. 37.011.3-051(092)

Михайло Лашко

\section{ПРОБЛЕМА НАРОДНОГО ВЧИТЕЛЯ У ТВОРЧІЙ СПАДЩИНІ М. ГРІНЧЕНКО}

Лашко М. В. Проблема народного вчителя у творчій спадщині М. Грінченко

У статті на основі аналізу маловідомих творів української просвітниці й педагога М. Грінченко (1863-1928) охарактеризовано іiї ідеї щодо народного вчителя, розглянуто вимоги до його особистості та виокремлено низку питань, які хвилювали діячку.

Ключові слова: народний учитель, школа, учні, творча спадщина, Марыя Грінченко.

Лашко М. В. Проблема народного учителя в творческом наследии М. Гринченко. 